\title{
Evaluation of the benefits of utilization of fly ash as a material for road subgrade
}

\author{
Nikola Obradović* \\ ${ }^{1}$ Faculty of Civil Engineering, University of Belgrade, Bulevar kralja Aleksandra 73, Belgrade, Serbia
}

\begin{abstract}
The assessment of potential effects of the application of fly ash in road construction was based on the results of tests of fly ash from two thermal power plants in Serbia and three characteristic soil types: the medium plasticity clay, silty-sandy clay and high plasticity clay. The physical and mechanical characteristics of the stabilization of the above three types of soils with different percentages of fly ash and stabilizers (cement/lime) were determined in the study, and pavement designs for three traffic levels, from 1,000 to 10,000 vehicles/day were developed. The savings that can be achieved by using fly ash are going up to $16.8 \%$ depending on the type of material in the subgrade and the level of traffic. The potential savings are higher if the subsoil has lower bearing capacity, and if the traffic level is higher.
\end{abstract}

\section{Introduction}

Fly ash has been used for several decades as an alternative material in construction, especially in road construction. In Serbia, in the last ten years, several research studies have been made. In the last four years, at the Faculty of Civil Engineering of the University of Belgrade, two studies were conducted $[1,2]$ on the possibility of the use of ash from the Nikola Tesla thermal power plants (TENT A and TENT), Kostolac and Kolubara, in the construction of roads and railways. The studies have shown that fly ash from thermal power plants is a suitable material for construction of embankments and soil stabilization from the perspective of physical and mechanical characteristics $[3,4,5]$. The main goal of this paper is to present possible savings in the costs of construction of road structure if only the fly ash were used in the subgrade or a stabilizer.

\section{Main assumptions}

The assessment is based on the cost of construction of a new road structure for two-lane roads, with an average width of $7 \mathrm{~m}$. The assessment has been carried out for three levels of traffic load, which cover over $90 \%$ of two-lane roads in Serbia, and which are expressed through the annual average daily traffic (AADT) and amount to 1000, 5000 and 10000 vehicles/day.

\footnotetext{
${ }^{*}$ Corresponding author: nobradovic@grf.bg.ac.rs
} 
Dimensioning of the road structure was carried out in accordance with standard SRPS U.C4.012:1980 - Design and construction of roads - New flexible pavement thickness design [6].

Calculation of the costs for the construction of a road structure was carried out on the basis of the Price List for the construction and modernization of roads issued by PE Roads of Serbia [7]. For all costs, transportation distance of up to $30 \mathrm{~km}$ was adopted. According to the Regulation of the government of the Republic of Serbia [8] the cost of procurement of fly ash equals zero, and for the transportation cost, a Price List [7] for the transport of bulk materials in a vehicle with load bearing capacity of $25 \mathrm{t}$ at a distance of $50 \mathrm{~km}$ was used. The comparison only covered work items that are different due to the use of ash in the construction of road structure.

The values of the obtained laboratory CBR [9] were used as representative value of load bearing capacity of soil or ash stabilized soil.

The basic assumption used in the estimate is that by improving the load bearing capacity of the soil in the subgrade the thickness of the unbound layers in the subbase course of the road structure is decreased. The calculation does not take into account the option with replacement of soil in subsoil because it depends on other project elements (primarily solving of the vertical alignment). If the option with replacement of soil in subsoil were taken into account, the costs of road structure without the use of fly ash would only be higher, which means that the savings from the use of ash in that case would be even greater.

\section{Input data}

\subsection{Traffic load}

The traffic load was calculated for a project period of 20 years, including traffic growth rate of $3 \%$ per year.

The calculation takes into account the structure of typical vehicles, which corresponds to roads with similar traffic load in Serbia. The load is expressed in the number of crossings of standard axes $80 \mathrm{kN}$, and the equivalence factors were calculated based on the axial loads given in the standard SRPS U.C4.010: 1980 - Design and construction of roads Determination of cumulative equivalent traffic axle loads for flexible pavement thickness design [10] for all vehicles except for a European truck, which is not included in the used standard, and for which real axle loads were taken for the calculation of the equivalence factor.

Table 1 shows the calculated projected traffic load on the project traffic lane for three levels of traffic load.

Table 1. Project traffic load

\begin{tabular}{|c|c|c|}
\hline Traffic load level & $\begin{array}{c}\text { AADT } \\
\text { (vehicles/day) }\end{array}$ & $\begin{array}{c}\text { Equivalent axle loading } \\
\text { (standard axles of } 80 \mathrm{kN} \text { ) }\end{array}$ \\
\hline 1 & 1.000 & 749.896 \\
\hline 2 & 5.000 & 4.526 .787 \\
\hline 3 & 10.000 & 9.435 .191 \\
\hline
\end{tabular}




\subsection{Prices of work}

Costs for individual work items are taken from the Price List [2]. Table 2 shows the costs for basic work items that were used in the analysis. It should be kept in mind that only those items that are different from the standard construction of the roadway due to the use of ash were used. The costs given in the Price List [2] are exclusive of VAT.

Table 2. Costs of certain work items according to the Pricelist [2]

\begin{tabular}{|c|c|c|c|}
\hline Item no. & Short description of work item & $\begin{array}{l}\text { Unit of } \\
\text { measure }\end{array}$ & $\begin{array}{c}\text { Unit } \\
\text { price } \\
\text { (EUR) }\end{array}$ \\
\hline 4.1.2. & Placing of gravel tampons with transport of up to $30 \mathrm{~km}$ & $\mathrm{~m}^{3}$ & 12.3 \\
\hline 4.2.2. & $\begin{array}{l}\text { Placing of crushed aggregate } 0-60 \mathrm{~mm} \text { with transport of up to } \\
\qquad 30 \mathrm{~km}\end{array}$ & $\mathrm{~m}^{3}$ & 14.6 \\
\hline 5.1.1. & $\begin{array}{c}\text { Mixing and machine placing of asphalt concrete made of } \\
\text { eruptive aggregate with the transport of aggregate to the } \\
\text { asphalt base and transportation of asphalt mixture (transport } \\
\text { distance up to } 30 \mathrm{~km} \text { ) }\end{array}$ & $\mathrm{t}$ & 63.9 \\
\hline 5.1.2. & $\begin{array}{c}\text { Mixing and machine placing of asphalt concrete made of } \\
\text { limestone aggregate with the transport of aggregate to the } \\
\text { asphalt base and transportation of asphalt mixture (transport } \\
\text { distance up to } 30 \mathrm{~km} \text { ) }\end{array}$ & $\mathrm{t}$ & 59.5 \\
\hline 5.1.6. & $\begin{array}{l}\text { Mixing and machine placing of BNS } 32 \text { made of limestone } \\
\text { aggregate with the transport of aggregate to the asphalt base } \\
\text { and transportation of asphalt mixture (transport distance up to } \\
\qquad 30 \mathrm{~km})\end{array}$ & $\mathrm{t}$ & 55.7 \\
\hline \multirow[t]{2}{*}{ 5.1.7. } & $\begin{array}{l}\text { Mixing and machine placing of BNS } 32 \text { made of gravel with } \\
30 \% \text { crushed aggregate with the transport of aggregate to the } \\
\text { asphalt base and transportation of asphalt mixture (transport } \\
\text { distance up to } 30 \mathrm{~km} \text { ) }\end{array}$ & $\mathrm{t}$ & 54.7 \\
\hline & $\begin{array}{l}\text { Transportation of bulk materials in a } 25 \mathrm{t} \text { vehicle at a distance } \\
\text { of } 50 \mathrm{~km}\end{array}$ & $\mathrm{t}$ & 3.5 \\
\hline
\end{tabular}

The adopted dry bulk density of soil material in the subgrade and fly ash that were used in the analysis are shown in Table 3.

Table 3. Assumed bulk density of material in the subgrade and fly ash

\begin{tabular}{|c|c|}
\hline Material & Dry bulk density $\left(\mathrm{kg} / \mathrm{m}^{3}\right)$ \\
\hline Medium plasticity clay (SOIL1) & 1500 \\
\hline Silty-sandy clay (SOIL2) & 1750 \\
\hline High plasticity clay (SOIL3) & 1660 \\
\hline $\begin{array}{c}\text { Fly ash from PP Kolubara (FA1) and PP } \\
\text { Kostolac (FA2) }\end{array}$ & 800 \\
\hline
\end{tabular}

The price of asphalt layers for a certain thickness of the grade is recalculated taking into account the bulk density of the placed layers according to Table 4 .

Table 4 Assumed bulk density of mounted asphalt layers

\begin{tabular}{|c|c|}
\hline Asphalt layer & Bulk density $\left(\mathrm{kg} / \mathrm{m}^{3}\right)$ \\
\hline Asphalt concrete made of eruptive aggregate & 2350 \\
\hline Asphalt concrete made of limestone aggregate & 2400 \\
\hline Bituminous base course & 2420 \\
\hline
\end{tabular}


The quantity of ash that needs to be transported and applied within various alternative solutions was determined on the basis of its percentage participation and bulk density of the particular soil type in the subgrade of the road structure. The price of mixing fly ash, cement or lime with local soil was estimated on the basis of the assumption that a mobile mixing plant with a capacity of $100 \mathrm{~m}^{3}$ per hour will be used and amounts to 1.83 EUR per cubic meter of material. The estimated depth of mixing is $30 \mathrm{~cm}$. The prices of the activator, cement and lime, which were used in the analysis, are shown in Table 5.

Table 5. Unit prices of activator

\begin{tabular}{|c|c|}
\hline Activator & Unit price (EUR/kg) \\
\hline Portland cement & 0,08 \\
\hline Lime & 0,04 \\
\hline
\end{tabular}

\subsection{Load bearing capacity of the material in the subgrade of road structure}

Load bearing capacity of the material in the subgrade of road structures estimated based on the value of the laboratory CBR. Tables 6,7 , and 8 show the values of CBR that were used in the calculation of the road structure for the three tested soil types. In this, it should be taken into account that the values adopted for the stabilized soil are lower than those obtained in order to take into account to some extent the possible variability of soil and ash at the landfill and to obtain a more realistic value of the effects of the use of ash.

Table .6. Load bearing capacity of medium plastic clay (SOIL1) without and with ash

\begin{tabular}{|c|c|c|c|c|}
\hline \multirow{2}{*}{ Type of ash } & $\begin{array}{c}\text { Dosage of fly ash } \\
(\%)\end{array}$ & Activator & $\begin{array}{c}\text { Dosage of activator } \\
(\%)\end{array}$ & CBR (\%) \\
\hline \multicolumn{3}{|c|}{ SOIL1 without ash } & 2.3 \\
\hline \multirow{3}{*}{ FA1 } & \multirow{2}{*}{15} & & & 15.0 \\
\cline { 4 - 5 } & & Portland-cement & 2.5 & 30.0 \\
\cline { 2 - 5 } & 100 & & 5.0 & 50.0 \\
\hline \multirow{2}{*}{ FA2 } & 10 & & & 8.0 \\
\cline { 2 - 5 } & 100 & & & 50.0 \\
\hline
\end{tabular}

Table 7. Load bearing capacity of silty-sandy clay (SOIL2) without and with ash

\begin{tabular}{|c|c|c|}
\hline Type of ash & Dosage of fly ash (\%) & CBR (\%) \\
\hline \multicolumn{2}{|c|}{ SOIL2 without ash } & 6.0 \\
\hline \multirow{2}{*}{ FA1 } & 15 & 15.0 \\
\cline { 2 - 3 } & 100 & 10.0 \\
\hline \multirow{2}{*}{ FA2 } & 15 & 15.0 \\
\cline { 2 - 3 } & 100 & 50.0 \\
\hline
\end{tabular}

Table 8. Load bearing capacity highly plastic clay (SOIL3) without and with ash

\begin{tabular}{|c|c|c|c|c|}
\hline Type of ash & $\begin{array}{c}\text { Dosage of fly ash } \\
(\%)\end{array}$ & Activator & $\begin{array}{c}\text { Dosage of activator } \\
(\%)\end{array}$ & CBR $(\%)$ \\
\hline \multicolumn{4}{|c|}{ SOIL3 without ash } & 4.6 \\
\hline \multirow{4}{*}{ FA1 } & \multirow{3}{*}{20} & & & 10.0 \\
\hline & & Lime & 8.0 & 50.0 \\
\hline & & Portland-cement & 3.0 & 30.0 \\
\hline & 100 & & & 10.0 \\
\hline \multirow{4}{*}{ FA2 } & \multirow{3}{*}{20} & & & 10.0 \\
\hline & & Lime & 10.0 & 50.0 \\
\hline & & Portland-cement & 3.0 & 30.0 \\
\hline & 100 & & & 50.0 \\
\hline
\end{tabular}




\section{Dimensioning of variant solutions of road structure}

Dimensioning of the variant solutions for three levels of traffic load and for three typical soil types in the subgrade was done in two basic steps:

- The required thickness of asphalt layers was estimated on the basis of traffic load and asphalt layers were adopted.

- For every soil type, the required thickness of the layers of the unbound aggregate is determined.

\subsection{Determination of thickness of asphalt layers}

Table 9 shows the required thickness of asphalt layers for all three levels of traffic load, as well as the adopted layers of the road structure. These layers are identical for all variant solutions of road structures with determined traffic load, regardless of the type of soil in the subgrade.

Table 9. Dimensioning of asphalt layers

\begin{tabular}{|c|c|c|c|}
\hline \multirow{2}{*}{$\begin{array}{c}\text { AADT } \\
\text { (vehic/day) }\end{array}$} & \multirow{2}{*}{$\begin{array}{c}\text { Required structural } \\
\text { number of asphalt layers } \\
\text { SN1 }\end{array}$} & \multicolumn{2}{|c|}{ Adopted asphalt layer } \\
\hline & & Type of layer & $\begin{array}{l}\text { Thickness } \\
(\mathrm{cm})\end{array}$ \\
\hline \multirow[b]{2}{*}{1000} & \multirow[b]{2}{*}{3.99} & Surface course - AC 11 SURF & 4.0 \\
\hline & & $\begin{array}{l}\text { Bit. base course }- \text { AC 22A } \\
\text { BASE }\end{array}$ & 6.0 \\
\hline \multirow[b]{2}{*}{5000} & \multirow[b]{2}{*}{5.92} & Surface course - AC 11s SURF & 5.0 \\
\hline & & $\begin{array}{l}\text { Bit. base course- AC32sA } \\
\text { BASE }\end{array}$ & 9.0 \\
\hline \multirow{2}{*}{10000} & \multirow{2}{*}{6.95} & Surface course - AC 11s SURF & 5.0 \\
\hline & & Bit. base course- BNS 32sA & 12.0 \\
\hline
\end{tabular}

\subsection{Determination of the required thickness of the substrate made of unbound aggregate}

The thickness of the substrate made of unbound aggregate is the product of traffic load and load bearing capacity of soil in the subgrade of the road structure. Tables 10, 11 and 12 show the required thickness of the unbound aggregate subbase in the function of the type of material in the subgrade, its load bearing capacity and the traffic load. In this, the use of a crushed aggregate with replacement coefficient of 0.14 was assumed. The adopted minimum thickness of this layer is $15 \mathrm{~cm}$.

Table 10. Required thickness of unbound layers of subbase to the subgrade of SOIL1 and FA

\begin{tabular}{|l|c|c|c|c|c|}
\hline \multirow{2}{*}{ Subgrade } & $\begin{array}{c}\text { CBR } \\
(\%)\end{array}$ & $\begin{array}{c}\text { AADT } \\
\text { (vehic/day) }\end{array}$ & $\begin{array}{c}\text { Required } \\
\text { structural } \\
\text { number of } \\
\text { unbound } \\
\text { subbase layers } \\
\mathrm{SN}_{2}\end{array}$ & $\begin{array}{c}\text { Required } \\
\text { thickness of } \\
\text { unbound } \\
\text { aggregate } \\
\text { subbase(cm) }\end{array}$ & $\begin{array}{c}\text { Adopted } \\
\text { thickness of } \\
\text { unbound } \\
\text { aggregate } \\
\text { subbase(cm) }\end{array}$ \\
\hline \multirow{2}{*}{ SOIL1 } & \multirow{2}{*}{2.3} & 1000 & 6.37 & 45.5 & 46 \\
\cline { 3 - 6 } & & 5000 & 7.59 & 54.2 & 55 \\
\cline { 3 - 6 } SOIL1+ & 10000 & 7.97 & 56.9 & 57 \\
\hline FA1 15\% & \multirow{2}{*}{15.0} & 5000 & 2.34 & 16.7 & 17 \\
\cline { 3 - 6 } & & 10000 & 2.61 & 18.6 & 19 \\
\hline
\end{tabular}




\begin{tabular}{|c|c|c|c|c|c|}
\hline Subgrade & $\begin{array}{l}\text { CBR } \\
(\%)\end{array}$ & $\begin{array}{c}\text { AADT } \\
\text { (vehic/day) }\end{array}$ & $\begin{array}{c}\text { Required } \\
\text { structural } \\
\text { number of } \\
\text { unbound } \\
\text { subbase layers } \\
\mathrm{SN}_{2}\end{array}$ & $\begin{array}{c}\text { Required } \\
\text { thickness of } \\
\text { unbound } \\
\text { aggregate } \\
\text { subbase }(\mathrm{cm})\end{array}$ & $\begin{array}{c}\text { Adopted } \\
\text { thickness of } \\
\text { unbound } \\
\text { aggregate } \\
\text { subbase }(\mathrm{cm})\end{array}$ \\
\hline \multirow{3}{*}{$\begin{array}{l}\text { SOIL1 }+ \\
\text { FA1 } 15 \%+\text { PC } 2.5 \%\end{array}$} & \multirow{3}{*}{30.0} & 1000 & 1.26 & 9.0 & 15 \\
\hline & & 5000 & 1.17 & 8.4 & 15 \\
\hline & & 10000 & 1.06 & 7.6 & 15 \\
\hline \multirow{3}{*}{$\begin{array}{l}\text { SOIL1 + } \\
\text { FA1 } 15 \%+\text { PC } 5.0 \%\end{array}$} & \multirow{3}{*}{50.0} & 1000 & 0.57 & 4.1 & 15 \\
\hline & & 5000 & 0.27 & 1.9 & 15 \\
\hline & & 10000 & 0.04 & 0.3 & 15 \\
\hline \multirow{3}{*}{ FA1 $100 \%$} & \multirow{3}{*}{10.0} & 1000 & 3.06 & 21.9 & 22 \\
\hline & & 5000 & 3.56 & 25.4 & 26 \\
\hline & & 10000 & 3.69 & 26.4 & 27 \\
\hline \multirow{3}{*}{$\begin{array}{l}\text { SOIL1 }+ \\
\text { FA2 20\% }\end{array}$} & \multirow{3}{*}{8.0} & 1000 & 3.49 & 24.9 & 25 \\
\hline & & 5000 & 4.12 & 29.4 & 30 \\
\hline & & 10000 & 4.29 & 30.6 & 31 \\
\hline \multirow{3}{*}{ FA2 $100 \%$} & \multirow{3}{*}{50.0} & 1000 & 0.57 & 4.1 & 15 \\
\hline & & 5000 & 0.27 & 1.9 & 15 \\
\hline & & 10000 & 0.04 & 0.3 & 15 \\
\hline
\end{tabular}

Table 11. Required thickness of unbound layers of subbase to the subgrade of SOIL2 and FA

\begin{tabular}{|c|c|c|c|c|c|}
\hline Subgrade & $\begin{array}{l}\text { CBR } \\
(\%)\end{array}$ & $\begin{array}{c}\text { AADT } \\
\text { (vehic/day) }\end{array}$ & $\begin{array}{c}\text { Required } \\
\text { structural number } \\
\text { of unbound } \\
\text { subbase layers } \\
\mathrm{SN}_{2}\end{array}$ & $\begin{array}{c}\text { Required } \\
\text { thickness of } \\
\text { unbound } \\
\text { aggregate } \\
\text { subbase }(\mathrm{cm})\end{array}$ & $\begin{array}{c}\text { Adopted } \\
\text { thickness of } \\
\text { unbound } \\
\text { aggregate } \\
\text { subbase }(\mathrm{cm})\end{array}$ \\
\hline \multirow{3}{*}{ SOIL 2} & \multirow{3}{*}{6.0} & 1000 & 4.08 & 29.1 & 30 \\
\hline & & 5000 & 4.87 & 34.8 & 35 \\
\hline & & 10000 & 5.09 & 36.4 & 37 \\
\hline \multirow{3}{*}{ SOIL $2+$ FA1 15\% } & \multirow{3}{*}{15.0} & 1000 & 2.34 & 16.7 & 17 \\
\hline & & 5000 & 2.61 & 18.6 & 19 \\
\hline & & 10000 & 2.66 & 19.0 & 19 \\
\hline \multirow{3}{*}{ SOIL 3 + FA2 15\% } & \multirow{3}{*}{15.0} & 1000 & 2.34 & 16.7 & 17 \\
\hline & & 5000 & 2.61 & 18.6 & 19 \\
\hline & & 10000 & 2.66 & 19.0 & 19 \\
\hline
\end{tabular}

Table 12. Required thickness of unbound layers of subbase to the subgrade of SOIL3 and FA

\begin{tabular}{|c|c|c|c|c|c|}
\hline Subgrade & $\begin{array}{c}\text { CBR } \\
(\%)\end{array}$ & $\begin{array}{c}\text { AADT } \\
\text { (vehic/day) }\end{array}$ & $\begin{array}{c}\text { Required } \\
\text { structural } \\
\text { number of } \\
\text { unbound } \\
\text { subbase layers } \\
\mathrm{SN}_{2}\end{array}$ & $\begin{array}{l}\text { Required } \\
\text { thickness of } \\
\text { unbound } \\
\text { aggregate } \\
\text { subbase }(\mathrm{cm})\end{array}$ & $\begin{array}{l}\text { Adoptedthickness } \\
\text { of unbound } \\
\text { aggregate } \\
\text { subbase }(\mathrm{cm})\end{array}$ \\
\hline \multirow{3}{*}{ SOIL 3} & \multirow{3}{*}{4.6} & 1000 & 4.67 & 33.4 & 34 \\
\hline & & 5000 & 5.59 & 39.9 & 40 \\
\hline & & 10000 & 5.86 & 41.9 & 42 \\
\hline \multirow{3}{*}{ SOIL $3+$ FA1 $20 \%$} & \multirow{3}{*}{10.0} & 1000 & 3.06 & 21.9 & 22 \\
\hline & & 5000 & 3.56 & 25.4 & 26 \\
\hline & & 10000 & 3.69 & 26.4 & 27 \\
\hline \multirow{2}{*}{$\begin{array}{l}\text { SOIL 3 + FA1 20\% } \\
+ \text { L } 8.0 \%\end{array}$} & \multirow{2}{*}{50.0} & 1000 & 0.57 & 4.1 & 15 \\
\hline & & 5000 & 0.27 & 1.9 & 15 \\
\hline
\end{tabular}




\begin{tabular}{|c|c|c|c|c|c|}
\hline Subgrade & $\begin{array}{c}\text { CBR } \\
(\%)\end{array}$ & $\begin{array}{c}\text { AADT } \\
\text { (vehic/day) }\end{array}$ & $\begin{array}{c}\text { Required } \\
\text { structural } \\
\text { number of } \\
\text { unbound } \\
\text { subbase layers } \\
\mathrm{SN}_{2}\end{array}$ & $\begin{array}{l}\text { Required } \\
\text { thickness of } \\
\text { unbound } \\
\text { aggregate } \\
\text { subbase }(\mathrm{cm})\end{array}$ & $\begin{array}{l}\text { Adoptedthickness } \\
\text { of unbound } \\
\text { aggregate } \\
\text { subbase }(\mathrm{cm})\end{array}$ \\
\hline & & 10000 & 0.04 & 0.3 & 15 \\
\hline \multirow{3}{*}{$\begin{array}{l}\text { SOIL } 3+\text { FA1 } 20 \% \\
+ \text { PC } 3.0 \%\end{array}$} & \multirow{3}{*}{30.0} & 1000 & 1.26 & 9.0 & 15 \\
\hline & & 5000 & 1.17 & 8.4 & 15 \\
\hline & & 10000 & 1.06 & 7.6 & 15 \\
\hline \multirow{3}{*}{ SOIL $3+$ FA2 20\% } & \multirow{3}{*}{10.0} & 1000 & 3.06 & 21.9 & 22 \\
\hline & & 5000 & 3.56 & 25.4 & 26 \\
\hline & & 10000 & 3.69 & 26.4 & 27 \\
\hline \multirow{3}{*}{$\begin{array}{l}\text { SOIL } 3+\text { FA2 20\% } \\
+ \text { L } 10.0 \%\end{array}$} & \multirow{3}{*}{50.0} & 1000 & 0.57 & 4.1 & 15 \\
\hline & & 5000 & 0.27 & 1.9 & 15 \\
\hline & & 10000 & 0.04 & 0.3 & 15 \\
\hline \multirow{3}{*}{$\begin{array}{l}\text { SOIL } 3+\text { FA2 20\% } \\
+ \text { PC } 3.0 \%\end{array}$} & \multirow{3}{*}{30.0} & 1000 & 1.26 & 9.0 & 15 \\
\hline & & 5000 & 1.17 & 8.4 & 15 \\
\hline & & 10000 & 1.06 & 7.6 & 15 \\
\hline
\end{tabular}

\section{Comparing the costs of construction of road structure}

Tables 13, 14 and 15 show the costs of construction of a road structure on an unmodified subgrade, and comparative costs for different forms of modification that were included in the study [2].

Table 13. Costs of construction of road structure for subgrade made of SOIL1 and FA

\begin{tabular}{|c|c|c|c|c|c|}
\hline $\begin{array}{l}\text { Mixture } \\
\text { No }\end{array}$ & Subgrade & $\begin{array}{c}\text { CBR } \\
(\%)\end{array}$ & $\begin{array}{c}\text { AADT } \\
\text { (vehicles/day) }\end{array}$ & $\begin{array}{c}\text { Price of road } \\
\text { constructionfor } \\
1 \mathrm{~km} \text { of road, } 7 \\
\mathrm{~m} \text { wide (EUR) }\end{array}$ & $\begin{array}{c}\text { Percentage in } \\
\text { relation to } \\
\text { soilwithoutstabiliz } \\
\text { ation by ash }\end{array}$ \\
\hline \multirow{3}{*}{0} & \multirow{3}{*}{ SOIL1 } & \multirow{3}{*}{2.3} & 1000 & 143,4 & 100.0 \\
\hline & & & 5000 & 194,6 & 100.0 \\
\hline & & & 10000 & 224,9 & 100.0 \\
\hline \multirow{3}{*}{ MS1-1 } & \multirow{3}{*}{ SOIL1 + FA1 15\% } & \multirow{3}{*}{15.0} & 1000 & 119,4 & 83.2 \\
\hline & & & 5000 & 163,4 & 84.0 \\
\hline & & & 10000 & 191,7 & 85.2 \\
\hline \multirow{3}{*}{ MS1-2 } & \multirow{3}{*}{$\begin{array}{l}\text { SOIL1 + FA1 15\%+ } \\
\text { PC } 2.5 \%\end{array}$} & \multirow{3}{*}{30.0} & 1000 & 123,6 & 86.2 \\
\hline & & & 5000 & 165,6 & 85.1 \\
\hline & & & 10000 & 193,9 & 86.2 \\
\hline \multirow{3}{*}{ MS1-3 } & \multirow{3}{*}{$\begin{array}{l}\text { SOIL1+ FA1 15\%+ } \\
\text { PC 5.0\% }\end{array}$} & \multirow{3}{*}{50.0} & 1000 & 129,8 & 90.5 \\
\hline & & & 5000 & 171,8 & 88.3 \\
\hline & & & 10000 & 200,1 & 89.0 \\
\hline \multirow{3}{*}{ MS1-4 } & \multirow{3}{*}{ SOIL1 + FA2 20\% } & \multirow{3}{*}{8.0} & 1000 & 11,4 & 89.3 \\
\hline & & & 5000 & 175,2 & 90.0 \\
\hline & & & 10000 & 204,5 & 90.9 \\
\hline \multirow{3}{*}{ FA1 } & \multirow{3}{*}{ FA1 100\% } & \multirow{3}{*}{10.0} & 1000 & 128,7 & 89.8 \\
\hline & & & 5000 & 174,8 & 89.8 \\
\hline & & & 10000 & 204,1 & 90.8 \\
\hline \multirow{3}{*}{ FA2 } & \multirow{3}{*}{ FA2 100\% } & \multirow{3}{*}{50.0} & 1000 & 121,6 & 84.8 \\
\hline & & & 5000 & 163,6 & 84.1 \\
\hline & & & 10000 & 191,9 & 85.3 \\
\hline
\end{tabular}


Table 14. Costs of construction of road structure for subgrade made of SOIL2 and FA

\begin{tabular}{|c|c|c|c|c|c|}
\hline $\begin{array}{l}\text { Mixture } \\
\text { No }\end{array}$ & Subgrade & $\begin{array}{c}\text { CBR } \\
(\%)\end{array}$ & $\begin{array}{c}\text { AADT } \\
\text { (vehic/day) }\end{array}$ & $\begin{array}{c}\text { Price of road } \\
\text { constructionfor } 1 \\
\mathrm{~km} \text { of road, } 7 \mathrm{~m} \\
\text { wide (EUR) }\end{array}$ & $\begin{array}{c}\text { Percentage in } \\
\text { relation to } \\
\text { soilwithoutstabilizat } \\
\text { ion by ash }\end{array}$ \\
\hline & \multirow{3}{*}{ SOIL2 } & \multirow{3}{*}{6.0} & 1000 & 127,1 & 100.0 \\
\hline & & & 5000 & 174,2 & 100.0 \\
\hline & & & 10000 & 204,5 & 100.0 \\
\hline \multirow{3}{*}{ MS2-1 } & \multirow{3}{*}{$\begin{array}{l}\text { SOIL2 }+ \\
\text { FA1 15\% }\end{array}$} & \multirow{3}{*}{15.0} & 1000 & 119,6 & 94.1 \\
\hline & & & 5000 & 163,7 & 94.0 \\
\hline & & & 10000 & 192,0 & 93.9 \\
\hline \multirow{3}{*}{ MS2-2 } & \multirow{3}{*}{$\begin{array}{l}\text { SOIL2 }+ \\
\text { FA2 15\% }\end{array}$} & \multirow{3}{*}{15.0} & 1000 & 119,6 & 94.1 \\
\hline & & & 5000 & 163,7 & 94.0 \\
\hline & & & 10000 & 192,0 & 93.9 \\
\hline \multirow{3}{*}{ FA1 } & \multirow{3}{*}{ FA1 100\% } & \multirow{3}{*}{10.0} & 1000 & 128,7 & 101.3 \\
\hline & & & 5000 & 174,8 & 100.3 \\
\hline & & & 10000 & 204,1 & 99.8 \\
\hline \multirow{3}{*}{ FA2 } & \multirow{3}{*}{ FA2 100\% } & \multirow{3}{*}{50.0} & 1000 & 121,6 & 95.7 \\
\hline & & & 5000 & 163,6 & 93.9 \\
\hline & & & 10000 & 191,9 & 93.8 \\
\hline
\end{tabular}

Table 15. Costs of construction of road structure for subgrade made of SOIL 3 and FA

\begin{tabular}{|c|c|c|c|c|c|}
\hline $\begin{array}{l}\text { Mixture } \\
\text { No }\end{array}$ & Subgrade & $\begin{array}{c}\text { CBR } \\
(\%)\end{array}$ & $\begin{array}{c}\text { AADT } \\
\text { (vehic/day) }\end{array}$ & $\begin{array}{l}\text { Price of road } \\
\text { construction for } 1 \\
\mathrm{~km} \text { of road, } 7 \mathrm{~m} \\
\text { wide (EUR) }\end{array}$ & $\begin{array}{l}\text { Percentage in relation } \\
\text { to soil without } \\
\text { stabilization by ash }\end{array}$ \\
\hline & & & 1000 & 131,2 & 100.0 \\
\hline & SOIL3 & 4.6 & 5000 & 179,3 & 100.0 \\
\hline & & & 10000 & 209,6 & 100.0 \\
\hline \multirow{3}{*}{ MS3-1 } & \multirow{3}{*}{$\begin{array}{l}\text { SOIL3 + FA1 } \\
20 \%\end{array}$} & \multirow{3}{*}{10.0} & 1000 & 125,2 & 95.5 \\
\hline & & & 5000 & 171,3 & 95.6 \\
\hline & & & 10000 & 200,6 & 95.7 \\
\hline \multirow{3}{*}{ MS3-2 } & \multirow{3}{*}{$\begin{array}{l}\text { SOIL3 + FA1 } \\
20 \%+\text { K } 8.0 \%\end{array}$} & \multirow{3}{*}{50.0} & 1000 & 129,8 & 98.9 \\
\hline & & & 5000 & 171,8 & 95.8 \\
\hline & & & 10000 & 200,1 & 95.4 \\
\hline \multirow{3}{*}{ MS3-3 } & \multirow{3}{*}{$\begin{array}{l}\text { SOIL3 + FA1 } \\
20 \%+\text { PC } 3.0 \%\end{array}$} & \multirow{3}{*}{30.0} & 1000 & 126,4 & 96.4 \\
\hline & & & 5000 & 168,4 & 93.9 \\
\hline & & & 10000 & 196,7 & 93.8 \\
\hline \multirow{3}{*}{ MS3-4 } & \multirow{3}{*}{$\begin{array}{l}\text { SOIL3 + FA2 } \\
20 \%\end{array}$} & \multirow{3}{*}{10.0} & 1000 & 125,2 & 95.5 \\
\hline & & & 5000 & 171,3 & 95.6 \\
\hline & & & 10000 & 200,6 & 95.7 \\
\hline \multirow{3}{*}{ MS3-5 } & \multirow{3}{*}{$\begin{array}{l}\text { SOIL3 + FA2 } \\
20 \%+\text { K } 10.0 \%\end{array}$} & \multirow{3}{*}{50.0} & 1000 & 132,7 & 101.1 \\
\hline & & & 5000 & 174,7 & 97.4 \\
\hline & & & 10000 & 203,0 & 96.8 \\
\hline \multirow{3}{*}{ MS3-6 } & \multirow{3}{*}{$\begin{array}{l}\text { SOIL } 3+\text { FA2 } \\
20 \%+\text { PC } 3.0 \%\end{array}$} & \multirow{3}{*}{30.0} & 1000 & 126,4 & 96.4 \\
\hline & & & 5000 & 168,4 & 93.9 \\
\hline & & & 10000 & 196,7 & 93.8 \\
\hline \multirow{3}{*}{ FA1 } & \multirow{3}{*}{ FA1 100\% } & \multirow{3}{*}{10.0} & 1000 & 128,7 & 98.1 \\
\hline & & & 5000 & 174,8 & 97.5 \\
\hline & & & 10000 & 204,1 & 97.4 \\
\hline \multirow{3}{*}{ FA2 } & \multirow{3}{*}{ FA2 100\% } & \multirow{3}{*}{50.0} & 1000 & 121,6 & 97.1 \\
\hline & & & 5000 & 163,6 & 95.5 \\
\hline & & & 10000 & 191,9 & 95.6 \\
\hline
\end{tabular}


Figures 1, 2 and 3 show part of the results of the calculation of savings based on the performed tests, for different materials, according to the designations on the figures.

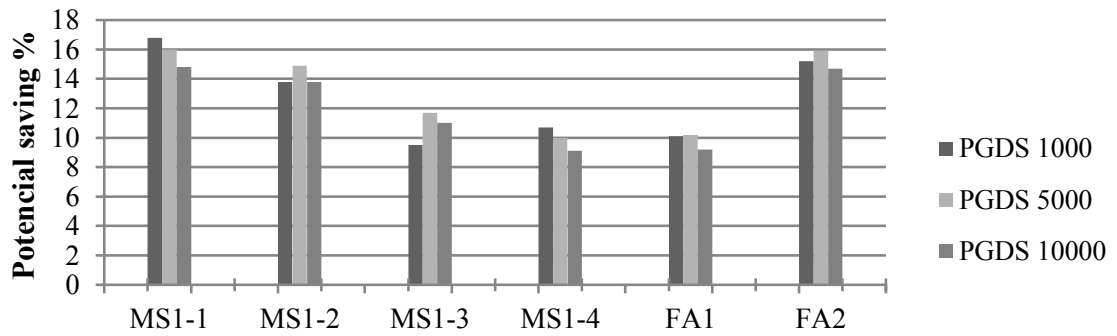

Figure 1. Price decrease of construction of road structure for subgrade made of SOIL1 and FA

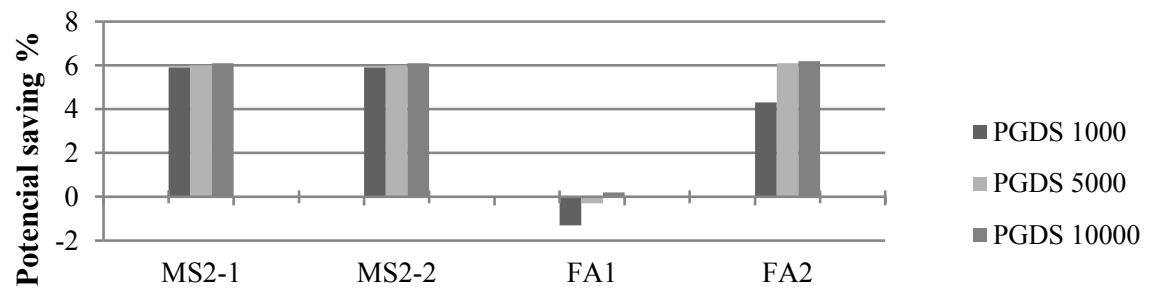

Figure 2. Price decrease of construction of road structure for subgrade made of SOIL2 and FA

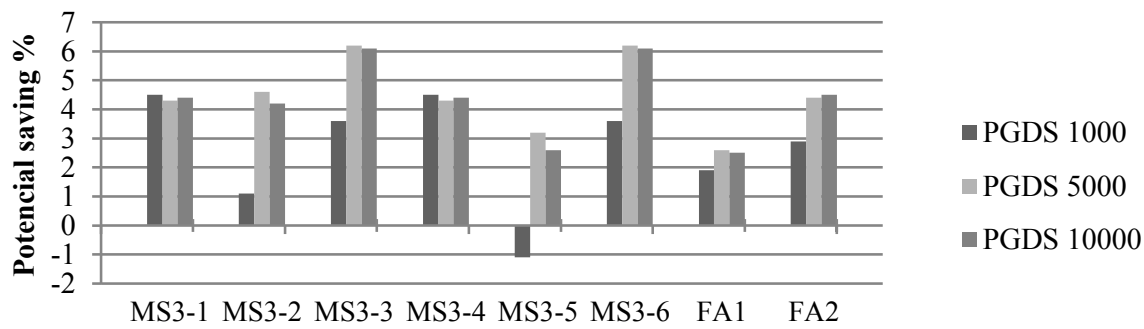

Figure 3. Price decrease of construction of road structure for subgrade made of SOIL3 and FA

\section{Conclusions}

Savings that can be achieved by using fly ash, depending on the type of soil in the subgrade and the level of traffic load, are up to $16.8 \%$ !

The softer soil and the higher the level of traffic load, the potential savings are more significant. In the case of medium plastic clay subgrade (SOIL1), the possible savings range from $9.1 \%$ to $16.8 \%$, while in the case of silty-sandy clay (SOIL2), the savings for the studied 
possibilities of stabilization of subgrade are from $5.9 \%$ to $6.1 \%$. In case of highly plastic clay (SOIL3) in subgrade, the savings that could be achieved are up to $6.2 \%$. The relatively large percentages of lime in the mixture causes that potential savings on low-traffic loads are relatively small. If only ash were used for the construction of the final layer of the subgrade, the possible savings would reach $15.9 \%$ in the case of subgrade made of medium plastic clay. When the subgrade is made of silty-sandy clay, potential savings are up to $6.2 \%$ for ash FA1, while in the case of ash FA2 there are no significant savings or potential costs are even higher, particularly for low traffic load. In the case of high-plastic clay, potential savings range from $2.5 \%$ for ash from FA1 to $6 \%$ for FA2 ash, depending on the level of traffic load.

For every facility for which the application of fly ash is considered, it is necessary to perform an appropriate feasibility study in order to, depending on the specific characteristics of the facility, such as the type and load bearing capacity of the soil in the subsoil and subgrade of the road structure, the design solution of the road (primarily the ratio of the vertical alignment and terrain) and transport distances the feasibility of the use of fly ash in layers of subgrade and road structure are determined.

The paper presents a part of the research carried out within the research project "The use of fly ash of thermal power plants on soil stabilization, self-placing and rolled concrete (RSS) with a discussion on the durability of cement mortars and fine-grained concrete", financed by the Electric Power Industry of the Republic of Serbia, and carried out by the Faculty of Civil Engineering of the University of Belgrade.

\section{References}

1. Utilization of fly ash and slag produced in the TPP JP EPS thermal power plants for construction of railways (University of Belgrade, 2015)

2. The use of fly ash of thermal power plants for soil stabilization, self-placing and rolled concrete (RSS) with a discussion on the durability of cement mortars and fine-grained concrete (University of Belgrade, 2014)

3. M. Vukićević, S. Maraš-Dragojević, S. Jocković, M. Marjanović, V. Pujević, Research results of fine-grained soil stabilization using fly ash from Serbian electric power plants, Proceedings of the 18th Int. Conf. on Soil Mechanics and Geot. Eng. "Challenges and Innovations in Geotechnics", Paris, France, 3267-3270 (2013)

4. M. Vukicevic, V. Pujević, et.al. Fine grained soil stabilization using class F fly ash with and without cement, Proc. of the XVI European Conf. on Soil Mechanics and Geotechnical Engineering Geotechnical Engineering for Infrastructure and Development, ECSMGE 2015, 5, 2671-2676, (2015)

5. M. Vukićević, Z. Popović, J. Despotović, L. Lazarević, Fly ash and slag utilization for the Serbian railway substructure, Transport, 33(2), 389-396 (2016)

6. SRPS U.C4.012:1980, Beograd

7. Cenovnik radova na izgradnji i modernizaciji puteva sa primenom od 01.04.2012. godine, (JP Putevi Srbije, Beograd, 2012)

8. Uredbu o tehničkim i drugim zahtevima za pepeo, kao građevinski materijal namenjen za upotrebu u izgradnji, rekonstrukciji, sanaciji i održavanju infrastrukturnih objekata javne namene, "Službeni glasniku RS", br. 56/2015 od 26.6.2015.

9. M. Vukićević, V. Pujević, M. Marjanović, S. Jocković, S. Maraš-Dragojević, GRAĐEVINAR, 67 (8), 761-770, doi: https://doi.org/10.14256/JCE.1281.2014 (2015)

10. SRPS U.C4.010: 1980 Srbije, Beograd 